\title{
Identifying a Research Agenda for Language Teaching Materials
}

\author{
SUE GARTON \\ Aston University
}

\author{
KATHLEEN GRAVES \\ University of Michigan
}

IN RECENT YEARS, LANGUAGE LEARNING materials, especially for English language learning, have gone from being a neglected area of research and publication to one that has gained serious attention, with a number of new publications (see, for example, Harwood, 2010; McGrath, 2013; Tomlinson, 2008, 2013; Tomlinson \& Masuhara, 2010a, as well as new editions of previous publications: McDonough, Shaw, \& Masuhara, 2013; Tomlinson, 2011). An important contribution to the field has also come from Tomlinson's (2012) state of the art review of materials development.

Two things are noticeable about the majority of these publications, however. First, the field is generally undertheorised. Many of the books published are 'how to' books, with advice for teachers (see, for example, McDonough et al., 2013; McGrath, 2002; Tomlinson, 2003, 2011). These books may draw on research and theory, especially in second language acquisition (SLA), but they are generally not based on research into materials.

The second point to be made is that the majority of previous publications focus on everything but the use of ELT materials. Thus we find books and chapters on materials design and development (Harwood, 2010; Jolly \& Bolitho, 2011; McGrath, 2002), materials evaluation and adaptation (Islam \& Mares, 2003; Littlejohn, 2011; McDonough et al., 2013; McGrath, 2002; Nation \& Macalister, 2010; Richards, 2001), the materials writing process (Bell \& Gower, 2011; Maley, 2003; Mares, 2003), and types of materials (Tomlinson, 2008). Any view of materials that neglects their actual use by teachers and/or

The Modern Language Journal, 98, 2, (2014)

DOI: $10.1111 / \mathrm{j} .1540-4781.2014 .12094 . \mathrm{x}$

0026-7902/14/654-657 \$1.50/0

(C) 2014 The Modern Language Journal learners can, in our view, only be partial, and yet none of the recent publications listed above focus on this aspect (but see Garton \& Graves, 2014).

It is precisely this lack of attention to materials in the classroom that is noted by Guerrettaz and Johnston (2013). In their important article, they indicate only two classroom-based studies with materials as the primary focus (Canagarajah, 1993; and Yakhontova, 2001). To this, we can add the work of Opoku-Amankwa (2010), whose ethnographic study looked at the interaction among teachers, learners, and textbooks in an urban primary school in Ghana. However, this remains an extremely small body of work.

Guerrettaz and Johnston have called for more research on the way materials (e.g., textbooks) actually function in the classroom, taking an important step toward developing a theoretical framework for materials use by adopting a classroom ecology approach. Such an approach enabled them to identify three principal areas in the classroom ecology with which materials interact: curriculum, classroom discourse, and language acquisition. In this article, we reflect on these three areas and point to future directions for research.

\section{THE CURRICULUM}

As Guerrettaz and Johnston note, in many contexts, materials-usually in the form of a coursebook-act as the de facto curriculum, influencing both what is taught and how. Within a materials-as-artefacts perspective, a number of writers identify principles for the inclusion of topics and language in materials (see, for example, McGrath, 2002; Tomlinson \& Masuhara, $2010 \mathrm{~b}$ ). The content of materials surely plays a significant role in the affordances for language learning. However, research is lacking on how content choices affect affordances and 
interactions in the classroom. Guerrettaz and Johnston note that in their data, interaction between learners and materials "seems to occur when connections can be made between the content of the materials and the students' lives" (p. 791). Their study suggests that the content of the material may play an important role in how these connections are made, yet in their data, connections were not generated by the students, but occurred through teacher prompts. This could be because the textbook used in their study focused exclusively on grammar and it may be argued that it is difficult for learners to make connections to content that is exclusively grammar-based. So an important question is what happens when materials are purposefully designed to foster such connections?

Attempts have been made to build such connections into materials through the use, for example, of locally produced as opposed to global coursebooks. López Barrios and Villanueva de Debat (2006) make the case that localising materials has the benefit of familiarity and connects them to the learners' world while also matching local practices and curriculum. However, the ways in which and to what extent learners will actually connect with materials in the classroom are complex and often unpredictable. Lee (1995), in her discussion of learner authenticity, identifies five factors that facilitate the interaction between learners and materials: the material, the learner, the teacher, the task, and the environment in which learning takes place. According to Lee, it is the interplay between these factors that contributes to learner authenticity, which occurs when materials "engage the learner's interest and impress him (sic) as being in some way relevant to his concerns" (Widdowson, 1978 , p. 90). These references are not recent, yet there appears to be little or no more recent research into the characteristics of materials that encourage learner connection, or authentication.

The second aspect of the relationship between materials and curriculum lies in curriculum implementation and the role that materials can play in classroom pedagogy. Writers such as Hutchinson and Torres (1994) and Masuhara and Tomlinson (2008), for example, maintain that materials can act as agents of change, supporting novice teachers or those who lack confidence. It is also often argued that appropriate coursebooks can facilitate curricular change by providing a visible framework that both teachers and students can follow (Rubdy, 2003) and they help teachers to "fully understand and 'routinize' change" (Hutchinson \& Torres, 1994, p. 323).

However, this may not always be the case. As Nur (2003) notes, where curricular change leads to new approaches in language teaching, teachers may need training to use the new books, otherwise they continue to employ previous methods. Humphries (2014) outlines a range of factors that affect a teacher's use of materials, including his/her understanding of language and how it is learned and of learners; the teacher's own experience of learning and confidence in English; and contextual factors such as the culture of the school and perceptions of the purposes for learning English. Studies such as that by Humphries show that when teachers are asked or required to use materials that do not match their expertise, experiences, and beliefs, they may not use the materials in the intended ways. Further classroom-based studies are needed into the complex interrelationship between materials, teacher cognition, and pedagogic practice in order to inform the management of curriculum change processes.

A final aspect of materials-as-curriculum is the role that adaptation and teacher-prepared materials may play in the classroom ecology. Adaptation of materials is generally acknowledged as important for meeting learners' needs (see, for example, McGrath, 2002). Guerrettaz and Johnston found evidence in their study that only the textbook constituted the legitimate curriculum of the class. In her work on textbook adaptation with a group of teachers in Ghana, Bosompem (2014) also draws attention to the power of the official book in some contexts. The teachers in her study, far from seeing adaptation as necessary for learners and the sign of a good teacher, felt guilty about questioning the authority of the book and unprepared to adapt it. While these studies point to attitudes toward adaptation, there is a lack of classroom-based studies into the actual patterns of teacher adaptations and their effect on students, or on teachers' use of supplementary or teacherprepared materials and learners' engagement with them.

\section{CLASSROOM DISCOURSE}

A key finding of Guerrettaz and Johnston is the role that materials play in the organization of classroom discourse. They show how materials can constrain classroom interaction, but also how they lead to unintended affordances for meaningful and extended discourse.

However, any discussion on the relationship between materials and classroom discourse needs 
to take into account that the language classroom represents a particular institutional context in which participants come together to achieve the specific goal of teaching and learning. Classroom discourse is therefore a form of institutional talk and as such has certain characteristics, described, for example, by Walsh (2006). The classroom must be seen, therefore, as a social context in its own right (Johnson, 1995; Walsh, 2002), with its own goals and rules of communication (Seedhouse, 2004). Walsh (2002) notes that, in order to understand classroom discourse, the relationship between language use and pedagogic goals needs to be recognised.

Research into classroom interaction has focused on the ways in which teachers and learners co-construct the discourse, but we are not aware of any research that adds materials into the equation. As such, the discourse analysed in the Guerrettaz and Johnston study provides some revealing glimpses into this type of analysis. For example, as the teacher plays a strong mediating role in all of the interactions, it is difficult to make claims about the affordances (intended or otherwise) of the materials in isolation. Both Walsh (2006, 2011) and Seedhouse (2004) have developed frameworks for analysing classroom interaction that acknowledge a variety of pedagogic purposes in the classroom. These can constitute a useful starting point for research into the different roles that materials may play in classroom discourse according to pedagogic purpose.

\section{LEARNING}

While research into the effects of materials on language acquisition is undoubtedly desirable, Tomlinson and Masuhara (2010b) note that there are practical difficulties in carrying out such studies: They would have to be longitudinal, requiring considerable resources, and it would be extremely difficult, if not impossible, to control for variables influencing acquisition in a classroom situation. Given the complexities of the classroom environment it may not, therefore, be useful to see specific language learning outcomes as a separate area of investigation into materials use. Rather, the focus should be on classroom processes and the way in which the various factors we have previously identified interact in those processes.

\section{TECHNOLOGY}

Our reflections so far have centred on traditional materials, particularly textbooks. However, any classroom-based research agenda into materials would also need to consider technology. It is no exaggeration to say that developments in digital technology have revolutionised language learning materials and their role in the classroom (see Macaro, Handley, \& Walter, 2012, for a review of Computer Assisted Language Learning in primary and secondary education).

Particularly significant are the affordances given by technology for changing the roles of classroom participants through the potential for bottom-up classroom processes. The chapters in Thomas (2009) show the range of possibilities afforded for the joint development of materials by teachers and learners through the use of Web 2.0 tools, with chapters on Skype, mobile phones, Personal Learning Environments, social networking sites, podcasts, and weblogs, to name just a few. The use of digital audio and video, the internet, blogs, wikis, Virtual Learning Environments, and so on has put "the possibilities of the adaptation and creation of a broad range of language-learning materials into the hands of the teacher, but also into the hands of the learners" (Motteram, 2011, p. 304). Therefore, the use of technology shifts the nature of materials from artefact to process and, as such, can place the learner squarely at the centre of materials in a way that traditional materials have not been able to. The implications of this for curriculum, classroom discourse, and language learning provide a rich field for future investigations and should be at the centre of any research agenda on materials.

\section{REFERENCES}

Bell, J., \& Gower, R. (2011). Writing course materials for the world: A great compromise. In B. Tomlinson (Ed.), Materials development in language teaching (2nd ed., pp. 135-150). Cambridge: Cambridge University Press.

Bosompem, E. G. (2014). Materials adaptation in Ghana: Teachers' attitudes and practices. In S. Garton \& K. Graves (Eds.), International perspectives on materials in ELT. Basingstoke, UK: Palgrave Macmillan.

Canagarajah, S. (1993). Critical ethnography of a Sri Lankan classroom: Ambiguities in student reproduction through ESOL. TESOL Quarterly, 27, 601626.

Garton, S., \& Graves, K. (Eds.). (2014). International perspectives on materials in ELT. Basingstoke: Palgrave Macmillan.

Guerrettaz, A. M., \& Johnston, B. (2013). Materials in the classroom ecology. Modern Language Journal, 97, 779-796. 
Harwood, N. (Ed.). (2010). English language teaching materials: Theory and practice. Cambridge: Cambridge University Press.

Humphries, S. (2014). Factors influencing Japanese teachers' adoption of communication-oriented textbooks. In S. Garton \& K. Graves (Eds.), International perspectives on materials in ELT. Basingstoke: Palgrave Macmillan.

Hutchinson, T., \& Torres, E. (1994). The textbook as agent of change. ELT Journal, 48, 315-328.

Islam, C., \& Mares, C. (2003). Adapting classroom materials. In B. Tomlinson (Ed.), Developing materials for language teaching (pp. 86-100). London: Continuum.

Johnson, K. E. (1995). Understanding communication in second language classrooms. Cambridge: Cambridge University Press.

Jolly, D., \& Bolitho, R. (2011). A framework for materials writing. In B. Tomlinson (Ed.), Materials development in language teaching (2nd ed., pp. 107-134). Cambridge: Cambridge University Press.

Lee, W. (1995). Authenticity revisited: Text authenticity and learner authenticity. ELT Journal, 49, 323-328.

Littlejohn, A. (2011). The analysis of language teaching materials: Inside the Trojan horse. In B. Tomlinson (Ed.), Materials development in language teaching (2nd ed., pp. 179-211). Cambridge: Cambridge University Press.

López Barrios, M., \& Villanueva de Debat, E. (2006). Minding the needs of the Argentine learner: Global textbooks and their adapted versions for the local context. Folio, 10(2), 14-16.

Macaro, E., Handley, Z., \& Walter, C. (2012). State-ofthe-art-article. A systematic review of CALL in English as a second language: Focus on primary and secondary education. Language Teaching, 45, $1-43$.

Maley, A. (2003). Creative approaches to writing materials. In B. Tomlinson (Ed.), Developing materials for language teaching (pp. 183-198). London: Continuum.

Mares, C. (2003). Writing a coursebook. In B. Tomlinson (Ed.), Developing materials for language teaching (pp. 130-140). London: Continuum.

Masuhara, H., \& Tomlinson, B. (2008). Materials for general English. In B. Tomlinson (Ed.), English language teaching materials: A critical review (pp. 1737). London: Continuum.

McDonough, J., Shaw, C., \& Masuhara, H. (2013). Materials and methods in ELT (3rd ed.). Oxford, UK: Blackwell.

McGrath, I. (2002). Materials evaluation and design for language teaching. Edinburgh, UK: Edinburgh University Press.

McGrath, I. (2013). Teaching materials and the roles of EFL/ ESL teachers. London: Bloomsbury.

Motteram, G. (2011). Developing language-learning materials with technology. In B. Tomlinson (Ed.),
Materials development in language teaching (2nd ed., pp. 303-327). Cambridge: Cambridge University Press.

Nation, I. S. P., \& Macalister, J. (2010). Language curriculum design. New York: Routledge.

Nur, C. (2003). English language teaching in Indonesia: Changing policies and practical constraints. In W. K. Ho \& R. Y. L. Wong (Eds.), English language teaching in East Asia today: Changing policies and practices (pp. 163-172). Singapore: Eastern Universities Press.

Opoku-Amankwa, K. (2010). What happens to textbooks in the classroom? Pupils' access to literacy in an urban primary school in Ghana. Pedagogy, Culture E् Society, 18, 159-172.

Richards, J. C. (2001). Curriculum development in language teaching. Cambridge: Cambridge University Press.

Rubdy, R. (2003). Selection of materials. In B. Tomlinson (Ed.), Developing materials for language teaching (pp. 37-57). London: Continuum.

Seedhouse, P. (2004). The interactional architecture of the language classroom: A conversation analysis perspective. Malden, MA: Blackwell.

Thomas, M. (2009). Handbook of research on Web 2.0 and second language learning. New York: IGI Global.

Tomlinson, B. (Ed.). (2003). Developing materials for language teaching. London: Continuum.

Tomlinson, B. (Ed.). (2008). English language teaching materials: A critical review. London: Continuum.

Tomlinson, B. (Ed.). (2011). Materials development in language teaching (2nd ed.). Cambridge: Cambridge University Press.

Tomlinson, B. (2012). State-of-the-art-article: Materials development for language learning and teaching. Language Teaching, 45, 143-179.

Tomlinson, B. (Ed.). (2013). Applied linguistics and materials development. London: Bloomsbury.

Tomlinson, B., \& Masuhara, H. (Eds.). (2010a). Research for materials development in language learning. London: Continuum.

Tomlinson, B., \& Masuhara, H. (2010b). Published research on materials development for language learning. In B. Tomlinson \& H. Masuhara (Eds.), Research for materials development in language learning (pp. 1-18). London: Continuum.

Walsh, S. (2002). Construction or obstruction: Teacher talk and learner involvement in the EFL classroom. Language Teaching Research, 6, 3-23.

Walsh, S. (2006). Investigating classroom discourse. London: Routledge.

Walsh, S. (2011). Exploring classroom discourse: Language in action. London: Routledge.

Widdowson, H. G. (1978). Teaching language as communication. Oxford: Oxford University Press.

Yakhontova, T. (2001). Textbooks, contexts and learners. English for Specific Purposes, 20, 397-415. 